\title{
Boron Isotopic Ratio in Brazilian Red Wines: a Potential Tool for Origin and Quality Studies?
}

\author{
Cibele M. S. de Almeida, ${ }^{a}$ Ana Cristina Almeida, ${ }^{b}$ Tatiana D. Saint'Pierre ${ }^{b}$ and \\ José Marcus Godoy*,b \\ ${ }^{a}$ Laboratório de Ciências Químicas, Centro de Ciência e Tecnologia, \\ Universidade Estadual do Norte Fluminense Darcy Ribeiro, Avenida Alberto Lamego 2000, \\ Parque Califórnia, 28013-602 Campos dos Goytacazes-RJ, Brazil
}

${ }^{b}$ Departamento de Química, Pontifícia Universidade Católica do Rio de Janeiro, Rua Marquês de São Vicente, 225, Gávea, 22451-900 Rio de Janeiro-RJ, Brazil

For the first time, the boron isotopic ratio is reported for Brazilian red wines. The boron concentration, ${ }^{11} \mathrm{~B} /{ }^{10} \mathrm{~B}$ isotopic ratio and $\delta^{11} \mathrm{~B}$ were determined in 89 red wines produced in Campanha Gaúcha, Serra Gaúcha (SG), and Vale dos Vinhedos (VV) in South Brazil and Vale do São Francisco (VSF) in Northeast Brazil. A broad boron concentration range, $<0.07$ to $20.4 \mathrm{mg} \mathrm{L}^{-1}$, was observed, where a few values were above the maximum allowed concentration according to the International Code of Oenological Practices $\left(14.0 \mathrm{mg} \mathrm{L}^{-1}\right)$. The obtained ${ }^{11} \mathrm{~B} /{ }^{10} \mathrm{~B}$ ratios were quite different from those observed in the literature. The ratios were quite similar among the Southern Brazilian wine producing areas, but a large difference was observed when compared with the Northeastern wines, allowing for the differentiation between these two important Brazilian wine regions. The results have also shown that is possible, based on the boron isotopic ratio, to differentiate the Brazilian red wines from Chilean, Italian and Portuguese red wine.

Keywords: Brazilian red wines, boron isotopic ratio, ICP-MS, ICP OES, authenticity studies

\section{Introduction}

Boron has two natural isotopes, ${ }^{10} \mathrm{~B}(19.9 \%)$ and ${ }^{11} \mathrm{~B}$ $(80.1 \%),{ }^{1}$ and is an oligo-element essential to plant health and growth. In wines, boron is present in a concentration of 0.1 to $10 \mathrm{mg} \mathrm{L}^{-1}$, expressed as boric acid, ${ }^{2-4}$ with a maximum acceptable boric acid concentration of $80 \mathrm{mg} \mathrm{L}^{-1}$ (14 $\left.\mathrm{mg} \mathrm{L}^{-1} \mathrm{~B}\right)$, according to the International Organisation of Vine and Wine (OIV). ${ }^{5}$

The boron isotopic variation can be expressed either as the ${ }^{11} \mathrm{~B} /{ }^{10} \mathrm{~B}$ ratio or as $\delta^{11} \mathrm{~B},{ }^{6-10}$ where $\delta^{11} \mathrm{~B}$ is defined as: $\delta\left({ }^{11} \mathrm{~B}\right)(\% \mathrm{o})=\frac{\left({ }^{11} \mathrm{~B} /{ }^{10} \mathrm{~B}\right)_{\text {sample }}}{\left({ }^{11} \mathrm{~B} /{ }^{10} \mathrm{~B}\right)_{\text {standard }}} \times 1000$

where $\left({ }^{11} \mathrm{~B} /{ }^{10} \mathrm{~B}\right)_{\text {sample }}$ is the ${ }^{11} \mathrm{~B} /{ }^{10} \mathrm{~B}$ isotopic ratio of the sample and $\left({ }^{11} \mathrm{~B} /{ }^{10} \mathrm{~B}\right)_{\text {standard }}$ is the ${ }^{11} \mathrm{~B} /{ }^{10} \mathrm{~B}$ isotopic ratio according to the NIST 951a Boron Acid Isotopic Standard.

*e-mail: jmgodoy@puc-rio.br
Boron can be regarded as an important tracer for understanding mass transfer processes in terrestrial systems, which is of great interest in geochemical, biological and environmental sciences. ${ }^{11-16}$

According to Vorster et al.,,$^{7}$ if the natural variation in the ${ }^{11} \mathrm{~B} /{ }^{10} \mathrm{~B}$ ratio of the soil is reflected in the vines, it can become an important tool in provenance studies of agricultural products, such as wines, helping to minimize adulteration and fraud in these products.

The ${ }^{11} \mathrm{~B} /{ }^{10} \mathrm{~B}$ ratio has been applied in wine geographical provenance studies to elucidate the country or even region inside a country. Coetzee and Vanhaecke ${ }^{6}$ observed differences that allowed them to differentiate between wines produced in South Africa, France and Italy. Bruyn ${ }^{3}$ was able to observe differences among the soils and wines from the South African regions of Swartland, Stellenbosh and Robertson. Combining the boron isotopic ratio with elemental analysis, Vorster et al. ${ }^{7}$ and Coetzee et al. ${ }^{8}$ also classified the soils and wines from the Swartland, Stellenbosh, Robertson and Walker Bay regions. These authors claim that other South African regions could be 
included, aiming for the development of a fingerprint for each wine-producing area of the country.

Of course, the applied equipment directly influences the obtained uncertainty. Quadrupole inductively coupled plasma mass spectrometry (Q-ICP-MS) has poor precision (relative standard deviation $(\mathrm{RSD})=0.1-0.5 \%$ ) compared to thermal ionization mass spectrometry (TIMS) $(\mathrm{RSD}=0.002-0.005 \%)$ and multicollector ICP-MS (RSD $=0.2-0.002 \%)$. However, with careful control and optimization of its operation conditions, useful results for wine provenance studies can be obtained by applying Q-ICP-MS.,6-8

It should be pointed out that beside lead, which was also applied to Brazilian red wines, ${ }^{17}$ other isotopes have been utilized in viticulture, Santesteban et al. ${ }^{9}$ presented a review about this subject. Delta(D) and delta(O-18) are quite applied to mineral water provenance studies ${ }^{18}$ and its use could be extended to detect water addiction in wines. ${ }^{9}$ Grapevines are considered plants with $\mathrm{C} 3$ photosynthesis cycle and present a $\delta\left({ }^{13} \mathrm{C}\right)$ around $-25 \%$ o while sugar cane is a $\mathrm{C} 4$ plant with a $\delta\left({ }^{13} \mathrm{C}\right)$ about $-11 \%$, therefore, sugar addition will alter the observed delta value. ${ }^{9,19}$ However, water deficit could also alter the $\delta\left({ }^{13} \mathrm{C}\right)$ and has to be taken into account. ${ }^{9119}$ Particularly interesting is the application of $\delta\left({ }^{87} \mathrm{Sr}\right)$ since wine/soil delta values are close to one, ${ }^{8}$ but, the same authors showed that, in order to obtain better discrimination among the wine regions, smaller uncertainty is necessary and, in this direction, the application of boron had provided better results. ${ }^{8}$

The present study represents the first study of the boron isotopic ratio in Brazilian red wines. Sixty percent of the wine produced in Brazil is bottled outside of its producing region, making it difficult to trace its identity and follow its quality. ${ }^{20}$ Another characteristic is the organization of the production system based on producer cooperatives, which includes up to 370 families, resulting in wine that is produced from vines from different families and eventually involving different cities than the designated origin. Therefore, at the consumer level, one has to trust the information printed on the label, including the location of the vines and the presence of additives. Based on these arguments, we decided to perform the present work on wines bought at the consumer level to evaluate the application of boron content and boron isotopic ratio as a tool to evaluate the wine provenance and quality.

\section{Experimental}

\section{Sampling and sample treatment}

Information related to the involved wine regions, sample collection and sample treatment is described in detail by
Almeida et al. ${ }^{17} \mathrm{~A}$ total of 89 Brazilian red wines were analyzed: 10 from Campanha Gaúcha, 36 from Vale dos Vinhedos, 33 from Serra Gaúcha and 10 from Vale do São Francisco.

For the quantitative determination of boron by applying inductively coupled plasma optical emission spectrometry (ICP OES), the samples were diluted 1:100 with Milli-Q ${ }^{\circledR}$ quality water. Based on the obtained boron content, the samples were diluted accordingly to obtain a boron concentration of approximately $20 \mu \mathrm{g} \mathrm{L}{ }^{-1}$, in order to avoid dead-time corrections during isotopic ratio determination. ${ }^{17}$

\section{Reagents and standard solutions}

All solutions were prepared with Milli- ${ }^{\circledR}$ quality water. Suprapur nitric acid (65\%) (Merck) was used in the oxidation of the wine samples, mannitol (20\%) (Sanobiol) and PA-grade ethanol (Merck) were used in the matrix effects studies.

During the uncertainty and accuracy testing, the following standard reference materials (SRM) were applied: NIST SRM 951a, acid boric isotopic standard, $\left({ }^{10} \mathrm{~B} /{ }^{11} \mathrm{~B}=0.2473 \pm 0.00024\right)$ and $95 \%{ }^{10} \mathrm{~B}$-enriched NIST SRM 952, enriched acid boric isotopic standard, (94.949 $\left.\pm 0.005 \%,{ }^{10} \mathrm{~B} /{ }^{11} \mathrm{~B}=18.80 \pm 0.02\right)$. Stock solutions (10 $\mathrm{mg} \mathrm{L}^{-1}$ ) were prepared using $1 \% \mathrm{HNO}_{3}$ and preserved under refrigeration. The blank corresponds to $1 \% \mathrm{HNO}_{3}$, prepared using Suprapur nitric acid (65\%) and Milli-Q ${ }^{\circledR}$ quality water.

Instrumentation

The boron content was determined by applying an Optima 4300 DV ICP OES (PerkinElmer), equipped with a cyclonic chamber-type twister (Glass Expansion). The corresponding operational parameters are described in Table 1.

The boron isotope ratios were determined using an ICP-MS (Agilent, model 7500ce), equipped with an octopole reaction system (ORS), a low-flow nebulizer (MicroMist) connected to a quartz nebulizer chamber (Scott) mounted on a Peltier block, which was kept at $2{ }^{\circ} \mathrm{C}$, and a quartz torch with a $2.5 \mathrm{~mm}$ diameter injector. Nickel sampler and skimmer cones were utilized. Additional operational conditions are given in Table 1.

Isotopic ratio determination

Due to the large relative mass difference involved in the ${ }^{10} \mathrm{~B} /{ }^{11} \mathrm{~B}$ isotopic ratio measurement, which leads to enhanced mass discrimination effects, when using 
Table 1. Operating conditions, data acquisition modes and other information for the determination of boron concentration and isotope ratios by ICP OES and ICP-MS, respectively

\begin{tabular}{|c|c|c|}
\hline Common parameter & ICP-MS & ICP OES \\
\hline Forward power / W & 1400 & 1500 \\
\hline Radiofrequency / MHz & 27.12 , free running & 27.12 , free running \\
\hline Sample introduction & cross flow & $\begin{array}{c}\text { Twinnabar concentric } \\
\text { chamber }\end{array}$ \\
\hline Sample flow rate $/\left(\mathrm{mL} \mathrm{min}^{-1}\right)$ & 0.98 & 1.5 \\
\hline \multirow[t]{2}{*}{ Argon flow rates $/\left(\mathrm{L} \mathrm{min}^{-1}\right)$} & 16.00 (plasma) & 15.00 (plasma) \\
\hline & 0.95 (auxiliary) & 1.0 (auxiliary) \\
\hline Makeup gas / $\left(\mathrm{L} \mathrm{min}^{-1}\right)$ & 0.16 & 0.45 (nebulizer) \\
\hline Temperature $/{ }^{\circ} \mathrm{C}$ & 2 & - \\
\hline Nebulizer pump / rps & 0.1 & - \\
\hline Measured elements & Boron isotope ratios & $\begin{array}{l}\text { Boron wavelength: } \\
249.772 \mathrm{~nm}\end{array}$ \\
\hline \multicolumn{3}{|l|}{ Measured parameter } \\
\hline \multicolumn{3}{|l|}{ Integration time $/ \mathrm{s}$} \\
\hline${ }^{11} \mathrm{~B}$ & \multicolumn{2}{|c|}{0.40} \\
\hline${ }^{10} \mathrm{~B}$ & \multicolumn{2}{|c|}{0.10} \\
\hline Total time / s & \multicolumn{2}{|c|}{270} \\
\hline Scans per replicates & \multicolumn{2}{|c|}{100} \\
\hline Dead-time / ns & \multicolumn{2}{|c|}{31} \\
\hline Spectral peak processing & \multicolumn{2}{|c|}{ peak hopping } \\
\hline Scans for reading & \multicolumn{2}{|r|}{1} \\
\hline Reading/replicates & \multicolumn{2}{|r|}{3} \\
\hline Number of replicates & \multicolumn{2}{|r|}{3} \\
\hline
\end{tabular}

ICP-MS, the sequence proposed by Coetzee and Vanhaecke ${ }^{6}$ was applied: standard - sample 1 - standard - sample 2 standard.

The uncertainty in the mass bias correction factor $(\beta)$ and the uncertainty in the calculated atom ratio were derived as proposed by Godoy et al..$^{21}$

Although the mass bias correction was applied only during sample analysis and accuracy testing and not during the first method development steps, as ethanol affects the tests, a larger deviation from the certified value was applied as a decision criteria.

\section{Data analysis}

The boron isotope ratios were analyzed using one-way analysis of variance (ANOVA). The degree of discrimination among the different regions may be an indication of the possible application of this technique to verify the existence of significant differences among the regions.

\section{Results and Discussion}

\section{Matrix effects: carbon content}

Potential tailing effects of the ${ }^{12} \mathrm{C}$ peak on the ${ }^{11} \mathrm{~B}$ peak can lead to a higher ${ }^{11} \mathrm{~B} /{ }^{10} \mathrm{~B}$ ratio, as reported by Coetzee and Vanhaecke, ${ }^{6}$ mainly when dealing with samples with high carbon content. According to Barbaste et al. ${ }^{22}$ the effect of ethanol on the ${ }^{11} \mathrm{~B} /{ }^{10} \mathrm{~B}$ ratio can be reduced by using a cooled nebulizer chamber, as utilized in the present work.

If ethanol has an influence on the ${ }^{11} \mathrm{~B}$ peak, the ${ }^{11} \mathrm{~B} /{ }^{10} \mathrm{~B}$ ratio should increase with ethanol content. Solutions of NIST SRM 951a $\left(20 \mu \mathrm{g} \mathrm{L}^{-1}\right)$ were prepared containing $0.125,0.25,0.50$ and $1.0 \%$ ethanol. As shown in Table 2, an effect was not observed even at $1 \%$ ethanol, which corresponds to a wine sample diluted 1:10.

Table 2. Ethanol effect on the ${ }^{11} \mathrm{~B} /{ }^{10} \mathrm{~B}$ isotopic ratio

\begin{tabular}{lc}
\hline Sample & ${ }^{11} \mathrm{~B} /{ }^{10} \mathrm{~B}($ standard deviation $)$ \\
\hline $0.125 \%$ ethanol & $4.0510(0.0034)$ \\
$0.25 \%$ ethanol & $4.0485(0.0023)$ \\
$0.5 \%$ ethanol & $4.0514(0.0005)$ \\
$1 \%$ ethanol & $4.0560(0.0012)$ \\
\hline
\end{tabular}

Another possible way to investigate the ${ }^{12} \mathrm{C}$ effect on the ${ }^{11} \mathrm{~B} /{ }^{10} \mathrm{~B}$ ratio is by successive dilution of the wine sample, since wine contains organic compounds other than ethanol. As shown in Figure 1, a matrix effect was observed. At a wine dilution of 1:50, a very high ${ }^{11} \mathrm{~B} /{ }^{10} \mathrm{~B}$ ratio was observed due to the ${ }^{12} \mathrm{C}$ tailing effect on the ${ }^{11} \mathrm{~B}$ peak. The effect is quickly reduced, and minor changes were observed at dilutions higher than 1:100. As low boron concentrations lead to poor measurement statistics, a higher dilution should be applied only when the boron content allows.

\section{Mannitol effect}

Boron loss by volatilization during sample treatment steps, by evaporation or acid dilution, is a concern in studies involving this element. One important boron characteristic is the formation of cis-diol complexes with a large variety of organic compounds; however, the observed yield is variable..$^{23}$ Notwithstanding, it is known that mannitol is one of the most efficient polyalcohols for this purpose and is usually applied in the volumetric determination of boric acid. ${ }^{24}$

Based on this finding, to minimize boron loss, NIST SRM 951a solutions were prepared at different boron concentrations $\left(20,30\right.$ and $\left.100 \mu \mathrm{g} \mathrm{L}^{-1}\right)$ with and without the 


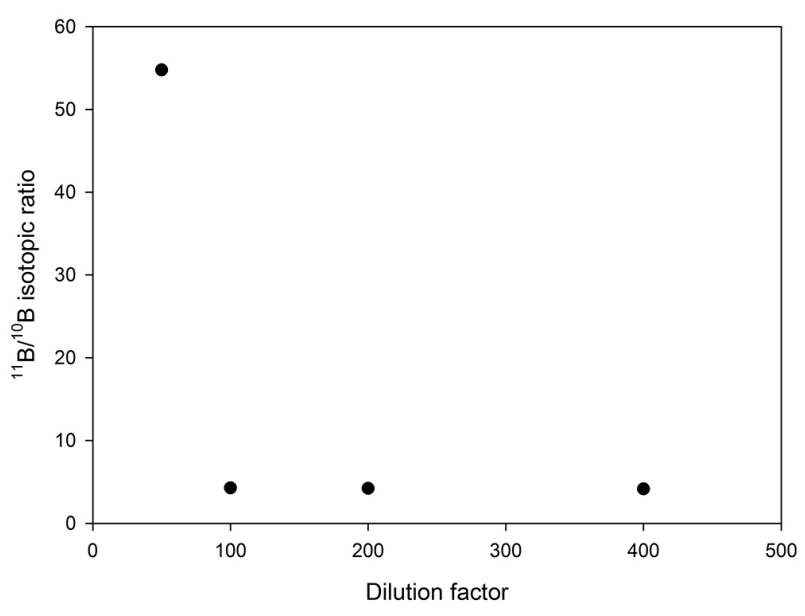

Figure 1. Sample dilution effect on the ${ }^{11} \mathrm{~B} /{ }^{10} \mathrm{~B}$ isotopic ratio in a red wine sample.

addition of mannitol ( $0.2 \%$ final concentration), as proposed by Bruyn. ${ }^{3}$ It should be noted that mannitol addition has the side effect of imparting a higher carbon content to the sample, showing the previously mentioned effect on the ${ }^{11} \mathrm{~B} /{ }^{10} \mathrm{~B}$ ratio. Therefore, the potential volatilization effect was verified by monitoring ${ }^{10} \mathrm{~B}$, while the ${ }^{12} \mathrm{C}$ influence was monitored based on the ${ }^{11} \mathrm{~B} /{ }^{10} \mathrm{~B}$ ratio. It was found that mannitol addition did not have the expected effect on the ${ }^{10} \mathrm{~B}$ intensity but did enhance the ${ }^{12} \mathrm{C}$ influence on the ${ }^{11} \mathrm{~B} /{ }^{10} \mathrm{~B}$ ratio. As a consequence, it was decided not to use mannitol addition.

\section{Boron concentration effect}

Based on our previous experience with lead, ${ }^{17}$ we decided to fix the boron concentration at approximately $20 \mu \mathrm{g} \mathrm{L}^{-1}$. However, as boron has a lower ionization efficiency than lead and higher optimal concentration $\left(100 \mu \mathrm{g} \mathrm{L}^{-1}\right)$ was proposed by Bruyn, ${ }^{3}$ Coetzee and Vanhaecke, ${ }^{6}$ Vorster et al. ${ }^{7}$ and Coetzee et al. ${ }^{8}$ we decided to investigate the influence of boron content, in particular, taking into account the necessity to work with a boron concentration that is as low as possible in order to minimize the ${ }^{12} \mathrm{C}$ effect. It was observed that between 10-30 $\mu \mathrm{g} \mathrm{L}{ }^{-1}$, despite of the existence of statistically valid differences among the isotopic ratio results, no clear trend on the ${ }^{10} \mathrm{~B} /{ }^{11} \mathrm{~B}$
Table 3. Boron concentration effect on the ${ }^{11} \mathrm{~B} /{ }^{10} \mathrm{~B}$ isotopic ratio $(\mathrm{n}=15)$

\begin{tabular}{lc}
\hline Solution & ${ }^{10} \mathrm{~B} /{ }^{11} \mathrm{~B}$ (standard deviation) \\
\hline NIST 951a, $10 \mu \mathrm{g} \mathrm{L}-1$ & $4.2626(0.0067)$ \\
NIST 951a, 20 $\mu \mathrm{g} \mathrm{L}^{-1}$ & $4.0733(0.0013)$ \\
NIST 951a, 30 $\mu \mathrm{g} \mathrm{L}^{-1}$ & $4.1203(0.0004)$ \\
NIST 951a, $100 \mu \mathrm{g} \mathrm{L}^{-1}$ & $4.9505(0.0065)$ \\
\hline
\end{tabular}

ratio was observed, may be due to the lack of mass bias correction. However, on the other hand, at $100 \mu \mathrm{g} \mathrm{L}{ }^{-1}$, the concentration effect is noticeable (Table 3).

Application to red wine samples: boron content and isotopic ratio determination

To test the achieved accuracy and precision, ten measurements on the $20 \mu \mathrm{g} \mathrm{L}^{-1}$ NIST SRM 951a solution were performed and the mass bias correction was applied. The obtained mean value and standard deviation were 0.2436 and 0.0053 , respectively, which is statistically equivalent $(95 \%)$ to the certified value $\left({ }^{10} \mathrm{~B} /{ }^{11} \mathrm{~B}=0.2473 \pm 0.00024\right)$. The relative standard error is approximately $0.5 \%$, which fits with the expected value for Q-ICP-MS.

Additionally, in order to test the accuracy, the boron isotopic ratio and boron content were determined for three Valpolicella wines bought in wine shops. The obtained values (Table 4) are in agreement with those published by Coetzee and Vanhaecke ${ }^{6}$ (mean value $=4.143, \mathrm{SD}=0.002$ ).

The obtained results for the Brazilian red wines are shown in Table S1, Supplementary Information. The boron concentration ranged between $<0.070$ and $20.4 \mathrm{mg} \mathrm{kg}^{-1}$. However, only a few brands presented values above $14 \mathrm{mg} \mathrm{kg}^{-1}$, the maximum allowed concentration proposed by the OIV. ${ }^{5}$ Four of them originated from the same winery (V6) but were produced from different vines. This finding may be related either to some local soil-specific characteristic or to a practice adopted by the winery. The other high concentration came from winery V7, where three wines were analyzed: two presented values below the detection limit and one presented $18.7 \mathrm{mg} \mathrm{kg}^{-1}$.

Table 4. Boron concentration and ${ }^{11} \mathrm{~B} /{ }^{10} \mathrm{~B}$ isotopic ratio on Italian red wine samples

\begin{tabular}{|c|c|c|c|c|c|}
\hline Sample & Region & Producer & Year & $\begin{array}{l}\text { Boron concentration } \\
\quad(\mathrm{SD}) /\left(\mathrm{mg} \mathrm{L}^{-1}\right)\end{array}$ & ${ }^{11} \mathrm{~B} /{ }^{10} \mathrm{~B}$ \\
\hline Valpolicella Classico Sartori & Verona & Casa Sartori & 2006 & $2.20(0.14)$ & 4.1157 \\
\hline Valpolicella, Bolla & Verona & Fatelli Bolla & 2004 & $3.3(0.4)$ & 4.1293 \\
\hline Valpolicella, San Marco & Verona & Cantine San Marco & 2007 & $1.05(0.10)$ & 4.1076 \\
\hline Mean value (SD) & & & & & $4.118(0.010)$ \\
\hline
\end{tabular}

SD: standard deviation. 
In fact, low boron concentrations are not expected for Vale dos Vinhedos wines. From a total of 36 samples, only three presented low values, two being from winery V7, which requires further study. In this direction, Vale dos Vinhedos is in fact a sub-region of Serra Gaúcha, and several Serra Gaúcha wines presented boron concentrations below the detection limit. The great majority of wines that presented concentration ranges below the limit of detection, mainly from the region of Serra Gaúcha, according to the information on the labels, are so-called "soft table" red wines. These wines are inferior in quality to those produced with Vitis vinifera grapes and are made from American red grapes, such as Isabel. Other wines from this region are fine red varietal wines made from Cabernet Sauvignon, Cabernet Franc, Merlot, Tannat and blends of these grapes. Some were produced by cooperatives, and most of them were from Bento Gonçalves/Vale dos Vinhedos.

The range of boron content in Brazilian wines was broader than those reported by Ozbek and Akman ${ }^{25}$ in Turkish red wines (7.94 to $10.7 \mathrm{mg} \mathrm{L}^{-1}$ ). For Portuguese wines, Rodrigues et al. ${ }^{26}$ were able to distinguish between wines from three wine regions, Alentejo, Dão and Bairrada, where Bairrada had the highest boron concentration (mean value of approximately $5.0 \mathrm{mg} \mathrm{L}^{-1}$ ). Hernandez et al. ${ }^{27}$ studied the boron content in wines of the region of Tacoronte-Acentejo (DOC region) and obtained a mean value of $7.0 \mathrm{mg} \mathrm{L}^{-1}$.

Among the three wine regions in Southern Brazil, Campanha Gaúcha presented the narrowest ${ }^{11} \mathrm{~B} /{ }^{10} \mathrm{~B}$ isotopic ratio range of 4.032-4.072. This reflects the fact that the analyzed wines from this region came from only two different wineries located in the same county.

As Vale dos Vinhedos represents a Serra Gaúcha sub-region, both presented similar ${ }^{11} \mathrm{~B} /{ }^{10} \mathrm{~B}$ isotopic ratio ranges of 3.857-4.094 and 3.799-4.088, respectively. It was not possible to distinguish these three Southern Brazilian winery regions based only on the boron concentration and ${ }^{11} \mathrm{~B} /{ }^{10} \mathrm{~B}$ isotopic ratio, similar to the results observed when applying lead isotopes. ${ }^{25}$

Also similar to the reported results for lead isotopes, ${ }^{17}$ the measured ${ }^{11} \mathrm{~B} /{ }^{10} \mathrm{~B}$ isotopic ratio of wines produced in the Vale do São Francisco region were distinguishably different from those produced in the Southern region. Thus, the ${ }^{11} \mathrm{~B} /{ }^{10} \mathrm{~B}$ isotopic ratio can be applied as a tool to differentiate these two Brazilian winery regions. Higher ${ }^{11} \mathrm{~B} /{ }^{10} \mathrm{~B}$ isotopic ratios of 4.110-5.152 were observed, and treating this last value as an outlier, the range becomes 4.110-4.173.

It was observed that the low ${ }^{11} \mathrm{~B} /{ }^{10} \mathrm{~B}$ isotopic ratio values of Serra Gaúcha wines is related to the boron content being lower than $1 \mathrm{mg} \mathrm{kg}^{-1}$, which can be connected to the ${ }^{10} \mathrm{~B}$ peak measurement statistics since the samples were diluted 1:100. Therefore, in further evaluations, only values associated with a boron concentration higher than this value were considered. Figure 2, where the ${ }^{11} \mathrm{~B} /{ }^{10} \mathrm{~B}$ isotopic ratio is plotted against the boron concentration, was built based on this guideline. The figure shows that it is possible to apply the ${ }^{11} \mathrm{~B} /{ }^{10} \mathrm{~B}$ isotopic ratio as a tool to differentiate between wines produced in the Southern region from those produced in the São Francisco Valley. It is also possible to verify that the ${ }^{11} \mathrm{~B} /{ }^{10} \mathrm{~B}$ isotopic ratio does not depend on the boron concentration in the wine. This boron differentiation among South and Northeastern regions becomes more clear when using a box plot (Figure 3).

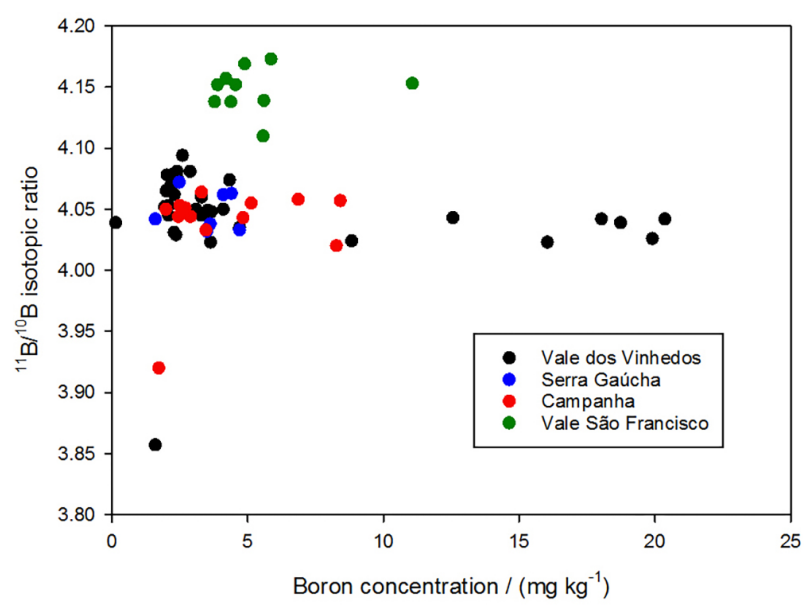

Figure 2. Variation in the ${ }^{11} \mathrm{~B} /{ }^{10} \mathrm{~B}$ isotopic ratios with boron concentrations for red wines produced in the Vale dos Vinhedos, Campanha Gaúcha, Serra Gaúcha and Vale do São Francisco regions.

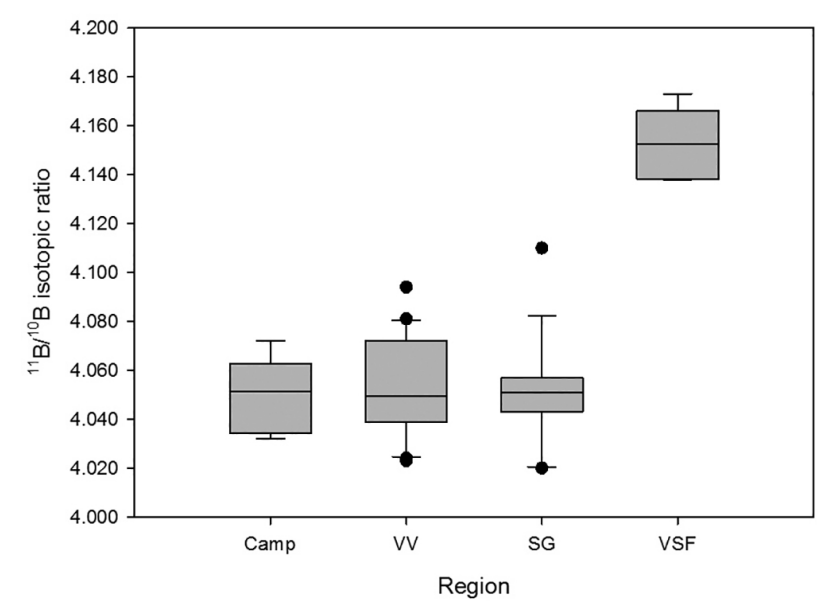

Figure 3. Box plot indicating the ${ }^{11} \mathrm{~B} /{ }^{10} \mathrm{~B}$ isotopic ratios of Brazilian red wine according to the producing region $(\mathrm{VV}=$ Vale dos Vinhedos, $\mathrm{SG}=$ Serra Gaúcha, VSF = Vale do São Francisco).

Table S2 (Supplementary Information) presents the boron concentrations and ${ }^{11} \mathrm{~B} /{ }^{10} \mathrm{~B}$ isotopic ratios of wines from Portugal, Italy, Spain, France, USA, South Africa, Chile and Argentina. Two French and two Spanish 
wines presented boron concentrations above the OIV maximum allowed concentration ( $\left.14 \mathrm{mg} \mathrm{L}^{-1}\right)$, while the remaining were between $<0.07$ and 9.0, as observed in the literature. ${ }^{4,-8-8,25-27}$ The boron isotopic ratios for Italian, French and South African wines have been reported in the literature, and the obtained values are in agreement with the expected ratios for the two wines sampled first. However, for the South African wines, only the first value fits with the expected value (4.185-4.223), and the other three are much higher. The first sample originated from West Cape, while the other three came from Stellenbosch and were produced by the same winery. As they were produced at the same winery, this may be related to the applied process and production additives.

Figure 4 shows a comparison between the boron isotopic ratio on Brazilian red wines and those observed on Argentinean, Chilean, Portuguese and Italian red wines, it is possible to verify that based on the ${ }^{11} \mathrm{~B} /{ }^{10} \mathrm{~B}$ isotopic ratio it is feasible to differentiate the Brazilian wines from the Chilean, Portuguese and Italian wines.

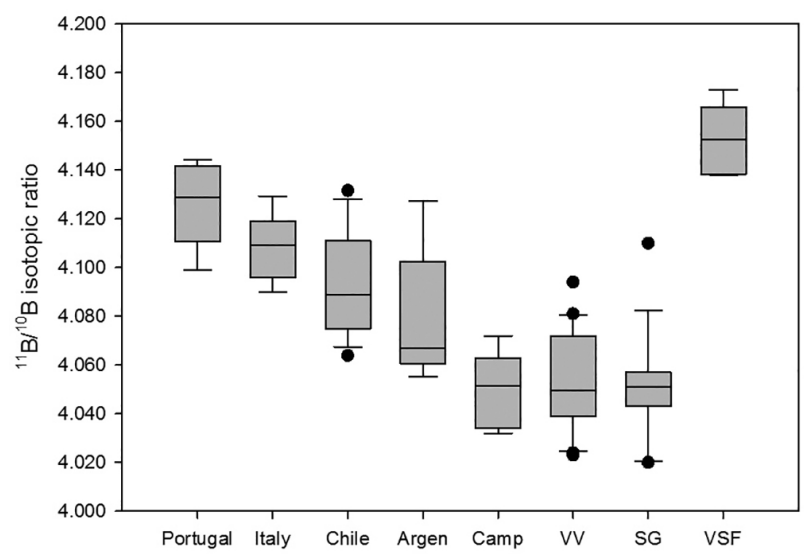

Figure 4. Box plot including ${ }^{11} \mathrm{~B} /{ }^{10} \mathrm{~B}$ isotopic ratio values on Brazilian red wines, according to the producing region, in comparison with the observed values for South American and European red wines (VV = Vale dos Vinhedos, SG = Serra Gaúcha, VSF = Vale do São Francisco).

\section{Conclusions}

The analyzed wine samples exhibited large variations in boron concentration. In wines from the Southern Brazilian region, the values ranged from $<0.07$ to $20.4 \mathrm{mg} \mathrm{L}^{-1}$, whereas in the Northeast region a narrow range of 3.8 to $11.1 \mathrm{mg} \mathrm{L}^{-1}$ was observed. From 94 samples, only five exceeded the OIV maximum allowed limit, with four being from the same winery. Similar to the analysis of lead isotopic ratios, based on the boron content together with its isotopic ratio, it was not possible to distinguish among the three Southern Brazilian vinery regions; however, it was possible to discriminate the South region from the
Northeastern region. Additionally, it was verified, that based on boron isotopic ratio, it is possible to discriminate the Brazilian red wines from the Chilean, Portuguese and Italian red wines.

\section{Supplementary Information}

Supplementary information is available free of charge at http://jbcs.sbq.org.br.

\section{Acknowledgments}

Cibele M. S. Almeida would like to say thank you for the fellowship from CNPq, Brazil. The authors would like also to express their gratitude to Embrapa Vinhos and Ruy Tonietto for their support during project formulation.

\section{References}

1. Berglund, M.; Wieser, M. E.; Pure Appl. Chem. 2011, 83, 397.

2. Catarino, S.; Curvelo-Garcia, A. S.; Sousa, R. B.; Cienc. Tec. Vitivinic. 2008, 23, 3.

3. Bruyn, R.; available at https://ujcontent.uj.ac.za/vital/access/ manager/Repository/uj:8639, accessed in January 2017.

4. Guo, W.; Wu, Z.; Hu, S.; Jin, L.; Qiu, K.; Guo, Q.; Gan, Y.; RSC Adv. 2016, 6, 47394.

5. The International Organisation of Vine and Wine, available at http://www.oiv.int/public/medias/3740/f-code-annexe-limitesmaximales-acceptables.pdf, accessed on October 20, 2016.

6. Coetzee, P. P.; Vanhaecke, F.; Anal. Bioanal. Chem. 2005, 383, 977.

7. Vorster, C.; Greeff, L.; Coetzee, P. P.; S. Afr. J. Chem. 2010, 63, 207.

8. Coetzee, P. P.; Greeff, L.; Vanhaecke, F.; S. Afr. J. Enol. Vitic. 2011, 32, 28.

9. Santesteban, L. G.; Miranda, C.; Barbarin, I.; Royo, J. B.; Aust. J. Grape Wine Res. 2015, 21, 157.

10. Wieser, M. E.; Yver, S. S.; Krouse, H. R.; Cantagallo, M. I.; Appl. Geochem. 2001, 16, 317.

11. Kaliwoda, M.; Marschall, H. R.; Marks, M. A. W.; Ludwing, T.; Altherr, R.; Markl, G.; Lithos 2011, 125, 52.

12. Vanderpool, R. A.; Johnson, P. E.; J. Agric. Food Chem. 1992, $40,462$.

13. Williams, L. B.; Hervig, R. L.; Wieser, M. E.; Hutcheon, I.; Chem. Geol. 2001, 174, 445.

14. Williams, L. B.; Hervig, R. L.; Holloway, J. R.; Hutcheon, I.; Geochim. Cosmochim. Acta 2001, 65, 1769.

15. Williams, L. B.; Hervig, R. L.; Hutcheon, I.; Geochim. Cosmochim. Acta 2001, 65, 1783.

16. Noireaux, J.; Gaillardet, J.; Sullivan, P. L.; Brantley, S. L.; Procedia Earth Planet. Sci. 2014, 10, 218. 
17. Almeida, C. M. S.; Almeida, A. C.; Godoy, M. L. D. P.; Saint'Pierre, T. D.; Godoy, J. M.; J. Braz. Chem. Soc. 2016, $27,1026$.

18. Godoy, J. M.; Godoy, M. L. D. P.; Neto, A.; J. Geochem. Explor. 2012, 119-120, 1.

19. Martinelli, L. A.; Ometto, J. P. H. B.; Ferraz, E. S.; Victoria, R. L.; de Camargo, P. B.; Moreira, M. Z.; Desvendando Questões Ambientais com Isótopos Estáveis; Oficina de Textos: São Paulo, Brazil, 2009.

20. http://www.cnpuv.embrapa.br/publica/anais/cbve10/, accessed in February 2017.

21. Godoy, M. L. D. P.; Godoy, J. M.; Roldão, L. A.; Tauhata, L.; J. Environ. Radioact. 2009, 100, 613.

22. Barbaste, M.; Robinson, K.; Guilfoyle, S.; Medina, B.; Lobinski, R.; J. Anal. At. Spectrom. 2002, 17, 135.
23. Liakopoulos, G.; Stavrianakou, S.; Nikolopoulos, D.; Karvonis, E.; Vekkos, K.-A.; Psaroudi, V.; Karabourniotis, G.; Plant Soil 2009, 323, 177.

24. Alcarde, J. C.; Catani, R. A.; Souza, O. S.; An. Esc. Super. Agric., "Luiz de Queiroz”, Univ. Sao Paulo 1972, XXIX, 273.

25. Ozbek, N.; Akman, S.; Food Sci. Technol. 2005, 61, 532.

26. Rodrigues, S. M.; Otero, M.; Alves, A. A.; Coimbra, J.; Coimbra, M. A.; Pereira, E.; Duarte, A. C.; J. Food. Compos. Anal. 2011, $24,548$.

27. Herandez, G. G.; de La Torre, A. H.; León, J. J. A.; Food Chem. 1997, 60, 339.

Submitted: January 11, 2017

Published online: March 6, 2017 